\title{
Preliminary Study About Occupational Stress of Physicians and Nurses in Pediatric and Neonatal Intensive Care Units: the Balance Between Effort and Reward
}

\author{
Monalisa de Cássia Fogaça ${ }^{1}$ \\ Werther Brunow de Carvalho ${ }^{2}$ \\ Vanessa de Albuquerque Cítero ${ }^{3}$ \\ Luiz Antonio Nogueira-Martins ${ }^{4}$
}

\begin{abstract}
This study compared the balance between effort (E) and reward (R) among physicians and nurses working in pediatric (PED) and neonatal (NEO) Intensive Care Units. This descriptive cross-sectional study was carried out with 37 physicians and 20 nurses. The Effort-Reward Imbalance Questionnaire was used. Statistically significant differences were not found among physicians ( $p>0.05$ ) or nurses from PED and NEO in relation to $E$ and $R$ $(p>0.05)$. No statistically significant differences were found between physicians and nurses in PED in the several studied variables. Comparison between the professionals working in NEO revealed that physicians presented more over-commitment than nurses $(p=0.01)$. The organizational setting of NEO proved to be more demanding for physicians, exacting a greater commitment to their work, while demands presented in both units seemed to be the same for nurses.
\end{abstract}

Descriptors: Intensive Care Units; Pediatrics; Neonatology; Stress; Physicians; Nurses.

\footnotetext{
Universidade Federal de São Paulo, Brazil:

${ }^{1}$ Psychologist, Doctoral Student, e-mail: monalisa.cassia@uol.com.br.

2 Free Lecture, Faculty, e-mail: wertherbru.dped@unifesp.br.

3 Physician, Ph.D., Faculty, e-mail: vcitero@uol.com.br.

${ }^{4}$ Physician, Free Lecture, Associate Professor, e-mail: nogmart2004@yahoo.com.br.
}

Corresponding Author:

Monalisa de Cássia Fogaça

Rua Dr. Clemente Ferreira, 126 Apto 24

Santo Antonio

CEP: 09530-440 São Caetano do Sul, São Paulo, Brasil

E-mail: monalisa.cassia@uol.com.br 


\section{Estudo preliminar sobre o estresse ocupacional de médicos e enfermeiros em UTI pediátrica e neonatal: o equilíbrio entre esforço e recompensa}

O objetivo do estudo foi comparar o equilíbrio entre esforço $(E)$ e recompensa $(R)$ entre médicos de unidades de terapia intensiva pediátrica (PED) e neonatal (NEO) e entre enfermeiros das mesmas unidades. Este é estudo transversal descritivo com 37 médicos e 20 enfermeiros. O questionário Effort-Reward Imbalance foi utilizado. Não se encontrou diferença estatística entre médicos da PED e da NEO em relação ao E e R $(p>0,05)$. Da mesma forma, enfermeiros da PED e da NEO não diferiram estatisticamente em relação ao $E$ e $R(p>0,05)$. Comparando médicos com enfermeiros da $P E D$, não foram encontradas diferenças entre as variáveis estudadas. Em relação à comparação feita entre profissionais da NEO, encontrou-se maior supercomprometimento dos médicos do que de enfermeiros $(p=0,01)$. O ambiente organizacional da NEO mostrou-se mais exigente para os médicos, determinando maior comprometimento com o trabalho, enquanto que, para os enfermeiros de ambas as unidades, a demanda pareceu ser a mesma.

Descritores: Unidades de Terapia Intensiva; Pediatria; Neonatologia; Estresse; Médicos; Enfermeiros.

\section{Estudio preliminar sobre el estrés ocupacional de médicos y enfermeros en UTI pediátrica y neonatal: el equilibrio entre esfuerzo y recompensa}

El objetivo del estudio fue comparar el equilibrio entre esfuerzo $(E)$ y recompensa $(R)$ entre médicos de unidades de terapia intensiva pediátrica (PED) y neonatal (NEO) y entre enfermeros de las mismas unidades. Este es estudio transversal descriptivo con 37 médicos y 20 enfermeros. El cuestionario Effort-Reward Imbalance fue utilizado. No se encontraron diferencias estadísticas entre médicos de la PED y de la NEO en relación al E y $R(p>0,05)$. De la misma forma, enfermeros de la PED y de la NEO no tuvieron diferencias estadísticas en relación al $E$ y $R(p>0,05)$. Comparando médicos con enfermeros de la PED, no fueron encontradas diferencias entre las variables estudiadas. En relación a la comparación hecha entre profesionales de la NEO, se encontró un mayor súper compromiso de médicos de que de enfermeros $(p=0,01)$. El ambiente organizacional de la NEO se mostró más exigente para los médicos, determinando mayor compromiso con el trabajo, en cuanto que, para los enfermeros de ambas unidades, la demanda pareció ser la misma.

Descriptores: Unidades de Terapia Intensiva; Pedíatria; Neonatología; Estrés; Médicos; Enfermeros.

\section{Introduction}

Occupational stress is an important, current problem because the rates of temporary incapacitation, absenteeism and early retirement, among others, in the workforce are alarming. It is worth noting in this context that the changes experienced by most workers are mainly due to technical progress, transformation originating in world economic development, the migration of workers and changing demographic structures of the active population ${ }^{(1)}$.
Health professionals seem to suffer tension specifically related to occupational stress. They face high levels of stress at work, which increases in pediatric and neonatal intensive care units ${ }^{(2-7)}$. Professionals who work in these units might experience burnout syndrome ${ }^{(2-5)}$, excessive workload, diminished satisfaction at work, in addition to psychological disorders ${ }^{(3)}$. Hence, stress and health problem risks appear when work demands do not 
adjust with workers' needs, expectations or skills.

Reactions to stressful work-related situations or situations that are characterized by high required effort to perform a task and low financial or emotional reward for performing the task can be evaluated by the balance between effort and reward through the Effort-Reward Imbalance $(E R I)^{(8)}$. For researchers ${ }^{(1,8)}$, the term reward originates from the following statement contained in the model's theoretical construction: work in adulthood sets a crucial link between self-regulatory functions such as self-esteem and self-efficacy, and the social opportunity structure. Thus, work has the role of emotional and motivational self-regulation and these aspects are essential to enable changes in social life. The concept of effort is used as part of a search process of socially organized exchange at work, to which society contributes in terms of reward. The balance between effort and reward is achieved when the worker is able to actively or passively overcome problems. The model assumes that situations in which there is no reciprocity between effort and reward continually cause emotional and physiological reactions in workers. In general, discrepancies between effort exerted and rewards received at work are considered detrimental in terms of tension reactions and their harmful effects on health ${ }^{(8-11)}$.

From this perspective, three recent Brazilian studies that evaluated intensive care nurses and physicians ${ }^{(12-}$ 14) are worth highlighting. These studies show that the presence of stress in this occupational environment produces dissatisfaction at work, affects physical health, leads to feelings of suffering arising from relationships with patients and their family members, teamwork, rotation of employees, absenteeism and the complex technology present in these areas in addition to the high prevalence of burnout syndrome in physicians.

In agreement with these studies and using the ERI model, which describes situations in which there is no reciprocity between effort and reward at work, this study aimed to compare physicians and nurses working in pediatric and neonatal ICUs regarding effort and reward balance. The study also evaluates whether there are any differences between effort and reward in the same professional category but in different contexts of providing intensive care.

\section{Method}

This descriptive cross-sectional study was carried out using a non-randomized sample that included physicians and nurses working in the pediatric (35) and neonatal (22) ICUs in the Federal University of São Paulo/Paulista School of Medicine (UNIFESP/EPM). Twenty-five physicians and 10 nurses from the pediatric ICU and 12 physicians and 10 nurses from the neonatal ICU, totaling 57 professionals agreed to participate in the study. The inclusion criterion consisted of being a physician or a nurse hired to work in the ICU or being a resident physician, and attending the ICU's supervised training. Distribution of sample loss is presented in Table 1 . Sample loss (50\%) occurred by non-returned instruments.

Table 1 - Number of professionals in ICUs invited to participate in the study

\begin{tabular}{lccccc}
\hline & \multicolumn{2}{c}{ Physicians } & & \multicolumn{2}{c}{ Nurses } \\
\cline { 2 - 3 } \cline { 5 - 6 } & Accepted & $\begin{array}{c}\text { Did not } \\
\text { accept }\end{array}$ & & Accepted & $\begin{array}{c}\text { Did not } \\
\text { accept }\end{array}$ \\
\hline Pediatric ICU & 25 & 26 & & 10 & 1 \\
Neonatal ICU & 12 & 28 & & 10 & 4 \\
Total & 37 & 54 & & 20 & 4 \\
\hline
\end{tabular}

The study was approved by the Research Ethics Committee at the UNIFESP/EPM and all participants signed free and informed consent forms.

Participants answered the Brazilian version of the Effort-Reward Imbalance $(E R I)^{(1)}$. The ERI describes situations in which there is no reciprocity between effort and reward at work. There are two sources of effort: extrinsic (work demands) and intrinsic (workers' individual motivation in the face of demands). The latter refers to the concept of "need of control" defined as standard to deal with work demands and contains two variables: vigor and immersion. Vigor is defined as active effort, with high probability of return (positive feedback) and immersion as a state of exhaustive competition ${ }^{(8)}$.

The instrument is composed of 46 items, divided in three parts: effort ( 6 items), reward (11 items) and over-commitment ( 6 items on the need for approval, 6 items on competitiveness, 8 items on irritability and 9 items on difficulty disengaging from the work environment). The answers for each item are evaluated in four levels ( $1=$ does not bother me; 2 =bothers me a little; 3 =bothers me a lot and $4=$ bothers me very much; or $1=$ I do not agree at all; $2=$ I do not agree; $3=$ I agree and $4=\mathrm{I}$ totally agree). The Cronbach's(15) alpha value for extrinsic effort is 0.68 , for reward at work is 0.78 and over commitment is 0.78 . The balance between effort and reward is given by the index $(\Sigma \mathrm{E} \div[\Sigma \mathrm{R} \times \mathrm{c}])$, where $\mathrm{E}=$ extrinsic effort and $\mathrm{R}=$ reward multiplied by correction factor ( $c=0.545455)$. As a result, values smaller than or 
equal to 1 indicate balance between effort and reward, while values higher than 1 indicate an imbalance between effort and reward.

In relation to the scale of over-commitment, a score above 19 points indicates a higher risk of developing occupational stress. Averages and remaining measures of the central tendency of variables of effort and reward and over-commitment were computed. Comparisons between units of work (pediatric and neonatal ICUs) and professional category (physicians and nurses) were analyzed using the Mann-Whitney $\mathrm{U}$.

\section{Results}

Physicians were predominantly female (76\%), average age of $34.70 \pm 7.11$ years and had worked in the ICU for an average of $7.17 \pm 6.89$ years. Nurses were also predominantly female (95\%), average age of $31.55 \pm 6.37$ years and worked in the ICU for an average of $5.85 \pm 4.40$ years.

Physicians' average of effort was $8.16 \pm 1.91$ in the pediatric ICU and $8.25 \pm 2.45$ in the neonatal ICU and statistically significant differences were not found $(p=0.92)$. In relation to the reward variable, the average values were $13.08 \pm 3.15$ in the pediatric ICU and $13 \pm 2.45$ in the neonatal ICU, statistically significant differences were not found $(p=0.84)$. Three physicians from the pediatric ICU and seven from the neonatal ICU presented over-commitment (12 and 58\% respectively, $\mathrm{p}=0.003$ ). The higher level of over-commitment among physicians in the neonatal ICU than among physicians in the pediatric ICU ( 26 and $16 \%$ respectively, $\mathrm{p}=0.01$ ) is mainly due to the highest need of approval (25 and
$6 \%$ respectively, $\mathrm{p}=0.02)$ and competitiveness (24 and $16 \%$ respectively, $p=0.04$ ). Applying the formula for calculating the balance between effort and reward revealed that physicians from both the pediatric and neonatal ICUs presented a relation with a slight increase in the effort variable in relation to reward at work (1.12 and 1.14 respectively) (Table 2 ).

Nurses from the pediatric ICU displayed a higher average of effort $(8.70 \pm 2.45)$ in relation to nurses in the neonatal ICU (7士1.33), with no significant differences $(p=0.12)$. In the analysis of the variable reward, the average value among nurses who work in the pediatric ICU was higher $(14.30 \pm 2.83)$ when compared to the neonatal ICU (13.20 \pm 3.05$)$ with no statistically significant differences $(p=0.23)$. Unlike physicians, three nurses from the pediatric ICU (30\%) and one from the neonatal ICU $(10 \%)$ revealed characteristics of over-commitment, though with no statically significant differences $(p=0.28)$. The computation for balance between effort and reward revealed that nurses in the pediatric ICU displayed a slight increase in effort in relation to reward (1.10) while nurses from the neonatal ICU were the only group with balance between measurements (0.95) (Table 2).

No statistically significant differences in any of the studied variables were found when physicians from the pediatric ICU were compared to nurses from the same unit. Statistically significant differences were found in the comparison between physicians and nurses from the neonatal unit $(p<0.05)$, revealing that physicians reported a higher over-commitment to work than nurses, specifically due to a higher irritability with work and difficulty disengaging from work (Table 2).

Table 2 - Results of comparisons between the pediatric and neonatal ICUs in the same professional category (physicians and nurses) and among different professional categories (physicians and nurses)

\begin{tabular}{|c|c|c|c|c|c|c|c|c|}
\hline & \multicolumn{3}{|c|}{ Physicians } & \multicolumn{3}{|c|}{ Nurses } & \multicolumn{2}{|c|}{$\begin{array}{c}\text { Physicians vs. } \\
\text { Nurses }\end{array}$} \\
\hline & PICU & NICU & $\mathbf{p}$ & PICU & NICU & $\mathbf{p}$ & PICU (p) & $\operatorname{NICU}(p)$ \\
\hline Index of balance between effort and reward & 1.12 & 1.14 & - & 1.10 & 0,95 & - & - & - \\
\hline Effort & 8.16 & 8.25 & 0.92 & 8.70 & 7 & 0.12 & 0.58 & 0.24 \\
\hline Reward & 13.08 & 13 & 0.84 & 14.30 & 13.20 & 0.23 & 0.10 & 0.78 \\
\hline Sum of scales of over commitment & 13.09 & 18.08 & 0.01 & 13.80 & 12.40 & 0.73 & 0.90 & 0.01 \\
\hline Need of approval & 3.64 & 4.92 & 0.02 & 4.20 & 4.20 & 0.85 & 0.32 & 0.11 \\
\hline Competitiveness & 1.48 & 2.67 & 0.04 & 1.90 & 1.60 & 0.78 & 0.55 & 0.13 \\
\hline Irritability & 3.79 & 4.58 & 0.30 & 3.40 & 2.80 & 0.97 & 0.32 & 0.02 \\
\hline $\begin{array}{l}\text { Difficulty to disengage from the work } \\
\text { environment }\end{array}$ & 4.60 & 5.92 & 0.10 & 4.30 & 3.80 & 0.70 & 0.92 & 0.03 \\
\hline
\end{tabular}

PICU = pediatric intensive care unit

$\mathrm{NICU}=$ neonatal intensive care unit 


\section{Discussion}

Data from this study initially reveal that each professional category present different responses in the face of organizational demands.

The variable immersion is present in the group of physicians from the neonatal ICU where vulnerability to occupational stress is more evident, that is, when physicians from the neonatal unit are compared to physicians in the pediatric ICU, the first present higher over-commitment due to their competitiveness and need for approval. Based on this information, physicians from the neonatal ICU have a higher level of need to control their workplace, which leads to an environment with high effort and low reward. These situations can be perceived as insufficient reward and return in the face of expended effort. This feeling might generate instability at work, sudden occupational changes, lack of opportunity for promotion, determining low control over occupational position(1).

In the comparison between the teams of the neonatal ICU and the pediatric ICU, the latter present higher values of effort and reward, hence higher overcommitment to work. The demands from work are high but the rewards that result from these demands are high as well, which might lead to competitiveness and irritability within the work team. However, the nursing team from the neonatal ICU was the only group, among the four studied groups, that reported balance between effort and reward in relation to work, which constitutes a standard of response compatible with the definitions of the concept of $\operatorname{rigor}^{(8)}$, in which workers have a greater chance of having a positive return for their work.

When different categories are compared within their own work units, physicians and nurses who compose the neonatal ICU display statistically significant values for the variables irritability and difficulty disengaging from work, which constitutes an organizational environment of great professional demand and work overload. The intense workload in the environment of neonatal intensive care has been addressed in previous studies ${ }^{(16-}$ 17). A possibility to be considered in this study is the larger number of beds in the neonatal ICU (20) compared to the pediatric $\operatorname{ICU}^{(9)}$.

In relation to the nursing team, we can say that the results presented here are in agreement with studies that used the ERI model as a resource to analyze organizational environments(18-19).
Another study using the ERI ${ }^{(20)}$ revealed that female physicians show high scores in the over-commitment variable when compared to male physicians. A study ${ }^{(21)}$ concomitantly using the ERI and Demand-Control instruments found that the over-commitment and control over work variables affect the physicians' physical health. When female physicians were evaluated by the same instruments, the effort variable had a strong impact on physical health, while the reward variable improved the score in mental health.

Even though in this study we do not evaluate differences of gender in the occupational environment associated with tension at work, the results suggest interpersonal conflicts in the workplace among the studied population.

This study utilizes a descriptive design with frequencies and was carried out in a single facility with a small sample. Half the sample did not return the instrument, which might have compromised the results. Despite these limitations, this (preliminary) study contributes to scientific understanding of the subject and provides information that can lead to potential outcomes, i.e. because unbalance between effort and reward is present in the medical work of both units, a longitudinal evaluation exploring the factors that lead to this unbalance should be carried out in the future, discriminating between intensive care physicians and resident physicians attending supervising training at the ICU. The rationale is that the latter might have exerted greater effort to perform tasks while having less experience. The task of the nursing team in both units, on the other hand, should be studied in a more descriptive way so that differences in the actions of these professionals in both units can be defined to investigate those that demand more effort and/or less reward among professionals in the neonatal ICU.

\section{Final Considerations}

Despite the limited number of participants, this study has important implications for future research carried out with the ERI instrument in intensive care units seeking to verify occupational factors and compare sociodemographic data with data on expended effort and reward from work with a view to provide tools for professionals of related fields so occupational risk factors are detected and reduced and also to orient workers to find appropriate ways to deal with demands from work. 


\section{References}

1. Guimarães LAM, Grubits S. Série Saúde Mental e Trabalho. $1^{a}$ ed. vol II. São Paulo (SP): Casa do Psicólogo; 2004.

2. Fields AL, Cuerdon TT, Brasseux CO, Getson PR, Thompson AE, Orlowski JP et al. Physician burnout in pediatric care medicine. Crit Care Med 1995 August; 23(8):1425-9.

3. Oates RK e Oates P. Stress and mental health in neonatal intensive care units. Arch Dis Child 1995 October; 72:F107-F110. 4. Fischer JE, Calame A, Detting AC, Zeier H, Fanconi S. Experience and endocrine stress responses in neonatal and pediatric critical care nurses and physicians. Crit Care Med 2000 September; 28(9):3281-8.

5. Arriortua $A B$, Cid JL, Álvarez AC, Escribano V, García LN, Carvavilla EP. Situación de burnout de los pediatras intensivistas españoles. An Esp Pediatr 2000 Marzo; 52:418-23.

6. Morrison WE, Haas EC, Shaffner DH, Garrett ES, Fackler JC. Noise, stress, and annoyance in pediatric intensive care unit. Crit Care Med 2003 January; 31(1):113-9.

7. Cronqvist $A$, Lützén $K$, Nyström $M$. Nurses' lived experiences of moral stress support in the intensive care context. J Nurs Manag 2006 October; 14:405-13.

8. Siegrist J. The model of effort-reward imbalance: theorical backgroud.: information and documentation - bibliographic references [online]. 1999. Available from: URL: http://www.uniduesseldorf.de/www/workstress/htm.

9. Vegchel N, Jonge J, Bakker AB, Schaufeli WB. Testing global and specific indicators of rewards in the Effort-Reward Imbalance Model: Does it make any difference? Europ J Work Org Psych 2002 July; 11(4):403-21.

10. Fahlen G, Peter R, Knutsson A. The Effort-Reward Imbalance model of psychosocial stress at the workplace - a comparison of ERI exposure assessment using two estimation methods. Work \& Stress 2004 January-March; 18(1):81-8.

11. Tsutsumi A, Kawakami N. A review of empirical studies on the model of effort-reward imbalance at work: reducing occupational stress by implementing a new theory. Soc Sci Med
2004 Mayo; 59:2335-59.

12. Cavalheiro AM, Moura Junior DF, Lopes AC. Estresse de enfermeiros com atuação em unidade de terapia intensiva. Rev Latino-Am Enfermagem 2008 Janeiro-Fevereiro; 16(1):29-35.

13. Martins JT, Robazzi MLCC. O trabalho de enfermeiro em unidade de terapia intensiva: sentimentos de sofrimento. Rev Latino-am Enfermagem 2009 Janeiro-Fevereiro; 17(1):52-8.

14. Barros DS, Tironi MOS, Nascimento Sobrinho CL, Neves FS, Bittencourt AGV, Almeida AM et al. Médicos plantonistas de unidades de terapia intensiva: perfil sócio-demográfico, condições de trabalho e fatores associados à síndrome de burnout. Rev Bras Ter Intensiva 2008 Julho-Setembro; 20(3):235-40.

15. Chor D, Werneck GL, Faerstein E, Alves MG, Rotenberg L. The Brazilian version of the effort-reward imbalance questionnaire to assess job stress. Cad. Saúde Pública 2008 January; 24(1):219-24.

16. Chance WG. The crisis in staffing neonatal intensive care units: a taste of things to come? CMAJ 1989 June; 140:1271-4. 17. Oates PR e Oates RK. Stress and work relationships in the neonatal intensive care unit: are they worse than in the wards? J Paediatr Child Health; 1996 September; 32 (1):57-9.

18. Bakker AB, Killmer $\mathrm{CH}$, Siegrist J, Schufeli WB. Effort-reward imbalance and burnout among nurses. J Adv Nurs 2000 August; 31(4):884-91.

19. Weyers S, Peter R, Boggild H, Jeppesen HJ, Siegrist J. Psychosocial work stress is associated with poor self-rated health in Danish nurses: a test of the effort-reward imbalance model. Scand J Caring Sci 2006 October; 20:26-34.

20. Buddeberg-Fischer B, Klagbofer R, Abel T, Buddeberg C. Junior physicians' workplace experiences in clinical fields in German-speaking Switzerland. Swiss Med Wkly 2005 January; 135:1926.

21. Li J, Yang W, Cho S. Gender differences in job strain, effortreward imbalance, and health functioning among Chinese physicians. Soc Sci Med 2006 March; 62:1066-77.

Received: Jul. 27th 2008

Accepted: Sep. $3^{\text {rd }} 2009$ 